\title{
INTRODUCTON: BRINGING JOBS BACK IN: TOWARD A NEW MULTI-LEVEL APPROACH TO THE STUDY OF WORK AND ORGANIZATIONS
}

\author{
M. Diane Burton \\ Lisa E. Cohen \\ Michael Lounsbury
}

\begin{abstract}
In this paper, we call for renewed attention to the structure and structuring of work within and between organizations. We argue that a multi-level approach, with jobs as a core analytic construct, is a way to draw connections among economic sociology, organizational sociology, the sociology of work and occupations, labor studies and stratification and address the important problems of both increasing inequality and declining economic productivity.
\end{abstract}

\section{INTRODUCTION}

Most adults spend the largest fraction of their waking hours working. What they do while working has important consequences for their own economic and physical well-being, the performance of their employing organization, and ultimately the kind of community and society in which they live. Surprisingly, although the structure and structuring of work has broad consequences, we have limited and contested understandings of how work tasks are divided and allocated across people and organizations. Broad questions about the structure of work have repeatedly come to the fore for more than a century: Who decides what tasks need to be done, what bundles of tasks belong together in a particular job, and what jobs belong in a particular organization? Who does particular jobs? Why are some jobs unique to a particular individual or organization but others more universal? Which jobs should be embedded in an employment relationship and which should be contracted on the market? Scholars have been addressing these questions for years, but our answers to date are woefully incomplete.

Questions about the structure of work are typically raised in the pursuit of deeper understandings of either stratification or of organizational performance, but rarely both together. The literatures are largely distinct. Studying work as a mechanism of stratification emphasizes its allocative and remunerative aspects; whereas, studying work as a production process emphasizes its relationship to other inputs such as capital and equipment. Early theorists of the industrial revolution recognized the mutuality between modes of production and social hierarchies, but these insights have receded as capitalist bureaucracies prevailed (Adler 2003). As we face a new post-industrial revolution, there is a growing need for a more unified body of knowledge about work as the key interface where individuals, organizations and society intersect. A richer understanding of work will enable us to design better policies for the development of talent at the societal level as well as 
more efficacious work systems at the organization level. It will reveal how new organizational forms and new labor market institutions interact to shape the opportunity structure and influence who gets ahead. It will shed new light on the determinants of work inequities related to social, legal, and economic structures and provide pathways to a better future.

In this paper we propose that jobs are a powerful analytic category through which we can develop a new body of knowledge about individuals, organizations, occupations and work. Jobs are a useful tool for a multi-level theorist in that they can be meaningfully nested within and between organizations, they may or may not be situated in an externally recognized occupational group, and they are vessels that host incumbents, but are malleable such that they can be molded and reshaped. All of these attributes allow - essentially require - analysts examining jobs to consider both the broader context and the worker who inhabits the role. As such, bringing jobs into the study of work and organizations will focus attention on both the micro- and macrostructures that simultaneously create a lived experience of work, a set of boundaries around roles and organizations, and economic outcomes for people, organizations, industries and economies.

We draw our inspiration (and our title) from two seminal papers: James Baron and William Bielby's 1980 article in American Sociological Review, "Bringing the firms back in: Stratification, segmentation and the organization of work." and Barley and Kunda's (2001) article in Organization Science, "Bringing work back in." These articles - and the bodies of work that both precede and follow them - represent a dialogue about the structure of work and its consequences. They bring together macro- and micro- sociological perspectives and represent the best of quantitative and qualitative traditions. They are deeply grounded in the observed reality of work and organizations and pose important questions about the nature of the society that emerges as a consequence of how work is structured within and between organizations.

A generation of scholars - ours - schooled during the heyday of organizational sociology when the emphasis was disproportionately laid on organizations and institutions with little regard for agents and actors, let alone lowly workers, was profoundly drawn to the idea that the study of work and firms would be the key to understanding social change and societal inequality (See Volume 28 of this series, edited by Schoonhoven and Dobbin (2010) for essays about this period). We were inspired to study how firm births and deaths affect career mobility (Haveman \& Cohen 1994), how seemingly similar firms were founded with very different employment practices that in turn shaped outcomes for both the firms and the people employed in them (Burton 2001), and how new social practices were adopted and adapted in an organizational population (Lounsbury 2001). But note that our focal point, and that of our peers, was organizations. To the extent we saw work and workers, we saw occupations and demographic characteristics.

The past quarter century has profoundly called into question the centrality of organizations, the primacy of occupations, and the relevance of traditional demographic categories like male/female and black/white. It is high time to revisit our understandings of the structure of work. 


\section{WHY STUDY THE STRUCTURE OF WORK?}

Work consumes disproportionate hours of our time and disproportionate attention of managers, organizational designers, policy makers and regulators. We know from extensive empirical research that how jobs are designed and how work is structured affects motivation and performance (Hackman and Oldham 1980), satisfaction (Parker and Wall 1998), and even physical well-being (Goh, Pfeffer \& Zenios, 2015). Because people spend so many of their waking hours working, the nature of work undeniably shapes their day-to-day lived experience. Work also shapes the future trajectories and life chances of workers and their families (Hout, 2015). Understanding the structure of work is, therefore, important for understanding social inequality.

Productive work is the engine of economic development. As such, managers and leaders necessarily attend to how work is designed. The structure of work shapes what the managerial and supervisory role entails. Does the manager coordinate activities, ensure compliance, or enable commitment? The structure of work also reflects and refracts the structure of the organization. Consider Barley's (1996, pp. 408-409) speculative commentary on the importance of work for understanding both organizations and management:

Suppose that work was changing such that expertise was becoming more technical, more unevenly distributed, and less readily formalized or rationalized. Under such conditions, society might witness the resurgence of lines of work organized along occupational rather than administrative lines (Freidson, 1973). Hierarchy and bureaucracy might then become less effective modes of organizing, not simply because the environment had become more turbulent but because authority of expertise and authority of position would less seamlessly coincide.

However, the processes by which forms of expertise get organized inside large, bureaucracies or in the context of small, "professional" firms or independent contractors is not at all well understood (Abbott, 1989; Freidson, 2001; Lounsbury, 2007). With the rise of market logics and the growing prominence of finance conceptions of control, it is not obvious that expertise can always provide an organizing counterweight to hierarchical forms of control (Davis, 2009; Fligstein, 1990). The structuring of work is often embroiled in broader cultural-political struggles involving competing institutional logics — broader meanings and practices related to institutional orders such as the market, corporation, family, and professions - that inform how work gets defined and organized in organizations and fields (Thornton, Ocasio \& Lounsbury, 2012).

Thus, just as work shapes the internal structure of organizations, it also shapes their external boundaries. How work is structured determines what can and cannot be contracted (Lounsbury, 2007; Pfeffer \& Baron 1988; Williamson 1985). As we learn from Alexander (2016), legal rights and obligations have important implications for the structure of work. The hard-fought gains by workers to ensure basic labor standards, ensure fairness in wages and hours, and protect themselves from health and safety risks all depend on shared understandings of work being organized under a single employer and structured in ways that can be measured, monitored and regulated. As the structure of work changes, existing laws and policies may no longer be 
appropriate or effective (Weil 2014). Consider emerging entrepreneurial organizations which are creating what is being referred to as the "gig economy." Gig economy firms build technological platforms that connect consumers who seek a service such as a ride (e.g. Uber) or a household helper (e.g. Task Rabbit) to a person who will provide the service. The gig economy firms insist that the service providers are independent contractors - entrepreneurs who are building their own businesses - not employees and that they are simply providing a matching service. Indeed, the business models of gig economy firms require that they be free from the expensive obligations of complying with wage and hour laws, ensuring safety standards, and providing benefits to workers. But current legal frameworks in the United State are based on an understanding that independent contractors have autonomy over how they perform their work and the prices that they set - neither is strictly true for most gig economy workers (Harris and Krueger, 2015 for a thoughtful discussion of these issues). Whether workers in the gig economy are employees or independent contractors is hotly contested and reveals why understanding the structure of work is important for designing effective organizations and developing responsible social policies.

Finally, as researchers and teachers, we need to understand how work is structured, with what consequences, and how it is changing over time in order to teach future managers and policy makers. In sum, we should care about the structure of work because it impacts people, organizations, policy and society.

\section{WHAT DO WE KNOW ABOUT THE STRUCTURE/STRUCTURING OF WORK?}

Over the past 200 years we have seen dramatic changes in how work is structured, first as part of the industrial revolution (Thompson, 1967) and more recently as the technologies of production (Adler, 2003; Autor, 2015), the scale and scope of firms (Chandler, 1990), and the institutional regimes governing the employment relationship such as employment regulation (Dobbin and Sutton, 1998) and unionization (Freeman and Medoff, 1984) have shifted.

The accepted narrative of the sweeping changes to the structure of work typically starts with agrarian society and cottage industries being displaced by mechanization and the industrial revolution. The first industrial revolution moved work from homes and farms and into factories and as people work for wages, the structure of work is transformed from being task-focused to being clock-focused (Thompson, 1967). The second industrial revolution dramatically increased the scale and complexity of organizations while simultaneously decreasing the variety and complexity of work.

As mechanization took hold, work was divided into narrow specializations and tasks became repetitive and monotonous. Smith's (1776) well-rehearsed description of pin manufacturing is the earliest exposition of the extreme division of labor that was believed to enhance productivity. These ideas were amplified and codified in Taylor's (1911) theory of Scientific Management. Weil (201, p 37) notes "an important piece of the management task facing corporations in the first half of the 1900s was hiring, training, evaluating, and compensating the thousands of people working within them." This led to the formalization of the human resources function (Baron, Dobbin, \& Jennings, 1986; Baron, Jennings, \& Dobbin, 1988), the development of internal labor markets (Doeringer \& Piore, 1971), and the golden era of unions, collective bargaining, and a growing middle class (Freeman \& Medoff, 1984). 
Work was structured in a bureaucratic hierarchy with ports of entry at the bottom of the hierarchy and transparent rules and procedures for advancing through the career ladder. Workers seemed satisfied to trade control over work tasks for employment stability, economic security and predictable wage growth. But below the surface industrial engineers, managers, and human resource professionals discovered that people were not as easy to engineer for efficiency as machines. Workers resisted and organizational psychologists were brought in to design jobs in ways that workers would be both motivated and productive. The culmination of these efforts was Hackman and Oldham's (1980) Job Characteristics Model, which became the dominant model of work design and a canon of both organizational behavior and human resource management.

Oldham and Hackman (2010), in a retrospective on their job characteristics theory, state:

Back when we were doing our own research on job design, organizational work generally was organized as a linked set of specific jobs, each set up to be performed by individuals who worked mostly independently of one another in bounded, stand-alone organizations. Those jobs were carefully analyzed and defined, both to establish pay rates and to remove any ambiguity about what jobholders were supposed to do. For information about virtually any job from abalone diver to zipper trimmer - scholars, as well as job seekers and human resource professionals, could turn to the comprehensive Dictionary of Occupational Titles (Miller, Treiman, Cain, \& Roos, 1980). One could learn all manner of things about specific jobs from the Dictionary - what qualifications are required, how risky they are, and even some of their motivational properties. (p. 465).

Even today, management and organizational behavior textbooks portray an uncomplicated image of how work is structured: Organizations have priorities and objectives. Organizational leaders define jobs and allocate tasks to achieve known priorities and objectives. Managers ensure that workers are hired into jobs and complete the requisite tasks. In this light, differences across organizations are attributed to differences in priorities and objectives.

But throughout this historical period, analysts have noted important variation within and between jobs and occupations and within and between organizations. Licht (1991), describing factories in Philadelphia between 1870 and 1960 asserts:

Proponents of scientific management techniques rarely succeeded in setting their innovations in place. Resistance from foremen who were threatened by these new consultants, more notable resistance from workers, and the administrative nightmare involved in cataloguing tasks and establishing rates particularly in firms whose product lines were always changing, as was the norm in Philadelphia - doomed most Tayloristic experiments from the start.

He goes on to critique occupational classifications more broadly: 
The real problem with relying on occupational listings, however, is that work is invariably treated in these analyses as an activity rather than as an experience. The source dictates the approach: tasks, product rendered, skill levels, and sectors of the economy provide the terms to define jobs - a person is a ditch digger, a candlestick maker, white-collar employee, or transport worker - and it is assumed that the nature and quality of the experience is thus known. Avoiding the titles and understanding the substance of jobs on a daily basis may produce more valuable ways of describing employment, as rewarding, steady, responsible, protected - "desirable" - for example, or lonely, hazardous, irregular, monotonous, exploitative - "lousy," if you will (this way of classifying occupations is deliberately fashioned on the primary and secondary labor market distinctions dawn by labor market segmentation theorists, distinctions properly made only by studying work directly)."(Licht, 1991, pp. 44-45)

This contrast between Hackman and Oldham's view of occupational classifications and that of Licht's view point to one of the persistent tensions in the study of work. What perspective matters most - that of the organization, or that of the worker? Is the point of studying the structure of work to develop a normative theory for managers and organizational designers, or is it to document the lived experience of workers?

\section{Five Lenses}

In reviewing the literature relevant to understanding the structure of work, five prevailing lenses become apparent: task, organization, system politics, institutional, and individual preferences. The lenses are born of different disciplinary traditions and obviously have different emphases, yet all purport to uncover important truths about the structure of work. We briefly review each before comparing and contrasting them.

The first lens, the task lens, focuses on the nature of work and the characteristics of tasks. This approach is embodied by Hackman and Oldham's Job Characteristics Model, but also evident in early structural/functionalist writings on bureaucracy. The core notion is that work is defined by the tasks that are required. Tasks can be bundled in ways that are more or less broad, but there are a clear set of things that must be accomplished.

The second lens, the organizational lens, highlights the role of the organization - typically a professionally managed bureaucratic organization - in structuring work. This is not surprising given that large organizations were, for much of the recent era when theories of work structure were being developed, the arena in which jobs and tasks are undertaken and enacted. As such employing organizations have shaped and constrained what is and is not possible in structuring jobs and work. Most of our theoretical models assume that the structuring of work is the structuring of organizations and the structuring of organizations is the structuring of work. Organizations should, therefore, be central to understanding the structure of work and vice versa. Contemporary human resource management takes this perspective for granted and takes responsibility for job analysis, job descriptions, recruiting and staffing, and performance appraisal. Indeed, the entire field of 'strategic human resource management' approaches the function as being in support of organizational priorities. 
The third lens, the system politics lens, has roots in Marxism and class conflict and is deeply embedded in the field of industrial relations. Through this lens, scholars and analysts see conflicting interests across groups. Sociologists who study the structure of work attend to demographic groups. For example, Strang and Baron (1990) document the proliferation of job titles - an indicator of how work is structured -- as being driven by privilege: demographic characteristics, professional power. They document ascriptive segregation by race and gender and social closure by powerful entities such as unions and the professions. This lens reveals ways that the structure of work is neither determined by the demands of the task nor the priorities of the organization, but instead through complex negotiations among competing groups.

The fourth lens draws from institutional analysis, and focuses on how broader societal pressures, including regulative, normative and cognitive (Scott, 2014), influence processes of work structuration (Lounsbury \& Kaghan, 2001). For instance, Edelman (1992) showed how staffing variation in Equal Employment Opportunity/Affirmative Action offices (EEO/AA) was shaped by differences in normative pressures experienced; she showed that government agencies, which experienced the greatest degree of normative pressure, created EEO/AA offices with a mean of 7.1 full-time salaried employees, whereas colleges and business organizations, which experienced less normative pressure, staffed offices with an average of two or fewer full-time salaried employees. Lounsbury (2001) similarly showed how recycling activism led to the creation of fully staffed, substantive recycling programs, whereas most recycling programs are more symbolic add-ons to conventional trash operations. Indeed, the institutional approach has much to contribute in the development of a broader research agenda on the evolutionary dynamics of organizations and occupations (Baron \& Bielby, 1980; Haveman \& Cohen, 1994; Miner, 1990, 1991), as well as the creation and dynamics of new organizations and their entrepreneurs (e.g., Baron, Hannan \& Burton, 1999; Burton \& Beckman, 2007; Burton, Sørensen, \& Beckman, 2002; Ferguson, Cohen, Burton \& Beckman, forthcoming).

The final lens, the individual preference lens, is of late the most fashionable in organizational psychology. It is epitomized in Grant and Parker's (2009) ideas of "relational' and "proactive" job design as well as Wrzniewski and Dutton's (2001) notion of "job crafting." The essence of the idea is that individuals have needs and preferences and should either seek or create jobs that cater to those needs and preferences and there is a thriving community of scholars investigating the individual and organizational benefits of individual job-crafting efforts - particularly those that are tied to social networks and positive affect.

While there is ample research and a coherent scholarly community within organizational behavior examining individual level action, there has been much less attention to collective level action that is shaped and constrained by external forces such as occupations, professions, legal regimes, cultural and institutional logics and competitive dynamics. And while some workers by the very nature of the work that they do - experts, professionals, and the self-employed - are afforded autonomy in how they complete their tasks, most are subject to workplace rules and requirements imposed by managers. Self-employment accounts for fewer than $11 \%$ of workers and has been relatively constant since 1990 (Hipple, 2010). Moreover, professionals and experts are increasingly situated within organizational bureaucracies (Briscoe, 2007). This implies that the focus on individuals as architects of their own jobs is at best overly optimistic. 
More generally, the sociological critique of organizational behavior approaches - either using the task lens or the individual lens - is that they are disconnected from the broader structures and politics of work. To date most scholars examining the structure of work do so from the confines of one particular lens. This is unfortunate, because the structure of work determines numerous and significant outcomes across levels: the way work is structured is tied to critical outcomes at the level of the worker, the organization, and the broader field (Cohen, 2013; Miner, 1990). It is also surprising in light of myriad calls from across the organization theory and organizational behavior communities to develop multi-level theories (e.g. Klein \& Kozlowski, 2000). Not only is work central to organizational structures, it is central to opportunity and institutional structures. Even today we have a surprisingly limited understanding of how employees and organizational leaders work out these and other shifts in different ways across different organizations in different industries, and fields. This is a reflection of a more general gap in knowledge at the interface of work and organizations.

Baron and Bielby (1980) were prescient in asserting that, "debates about the structure of work can best be advanced by clarifying the areas of conflict and complementarity among competing perspectives on work organization, specifically regarding the role of firms in mediating the links between social structure and processes at macro and micro levels." (p. 743). They recognized the importance of micro and macro perspectives for a rich understanding. And while their focus was on organizations as the most appropriate analytic unit, they saw the necessary interdependence among different levels of analysis and presaged multi-level theoretical approaches.

As the world of work has become more complex and distributed, existing theoretical tools and empirical evidence are not adequate to explain how and why organizations structure jobs and work in particular ways. Recent scholars point to sweeping changes such as globalization, financialization, and advanced technology as the drivers of such sweeping changes such as the fissuring (Weil, 2014) and "Nikefication" (Davis, 2016) of work, as well as the emergence of the "gig" economy (Barley \& Kunda, 2004). We agree, but also seek to better understand the onthe-ground mechanisms. Which kinds of jobs and tasks are vulnerable to change? How and when are new kinds of jobs formalized? Why do we see variation across seemingly similar firms in the way that they organize work? How does the broader institutional and cultural context, including laws, labor markets, and associations, interact to dampen or accelerate change? Answering these questions will require insights from all four lenses in combination. It will take a multi-level theory and an interdisciplinary conversation.

\section{NEED FOR MULTI-LEVEL THEORY}

The study of the structure and structuring of work is ripe for multi-level theory. All of the requisite theoretical foundations are in place and there is a strong base of empirical work. To borrow the words of Kaghan and Lounsbury (2011, pp. 78), a multilevel approach asks scholars to "empirically embrace a methodological groupism that richly and complexly embeds observed behavior in broader micro- and macrostructures, and to give these wider processes theoretical primacy in explaining processes of interest." 
This call is ever more urgent as the nature of work is, once again, changing. Sweeping forces such as technology and globalization are fundamentally altering the nature of work and imposing profound and pronounced changes on the structure of work within organizations. As Oldham and Hackman (2010) suggest:

It is true that many specific, well-defined jobs continue to exist in contemporary organizations. But we presently are in the midst of what we believe are fundamental changes in the relationships among people, the work they do, and the organizations for which they do it. Now individuals may telecommute rather than come to the office or plant every morning. They may be responsible for balancing among several different activities and responsibilities, none of which is defined as their main job. They may work in temporary teams whose membership shifts as work requirements change. They may be independent contractors, managing simultaneously temporary or semi-permanent relationships with multiple enterprises. They may serve on a project team whose other members come from different organizations suppliers, clients or organizational partners. They may be required to market their services within their own organizations, with no single boss, no home organizational unit, and no assurance of long-term employment (p. 466)

This description vividly captures the interrelationships among these lenses. It portrays individual choice and agency, organizational and task constraints, and the broader social context and conflict in which these opportunities are embedded. But more importantly, it highlights the importance of jobs as an analytic construct and the need to understand how jobs, as bundles of tasks, are embedded within and across organizations, social systems and institutions. Jobs are inhabited by individuals and individuals can shape jobs, but jobs are a distinct and separable analytic category.

\section{JOBS AS A FOCAL ANALYTIC CONSTRUCT}

Across the papers in this volume, jobs emerge as a focal construct in explaining the action at the intersection of individuals, work, structure, and organizations. This makes sense to us. Jobs by their very nature are a multi-level phenomenon and so provide a convenient, even ideal, vehicle for developing multi-level theory. Narrowly defined, jobs are "bundles of tasks performed by employees under administrative job titles" (Cohen, 2013, p. 432) but jobs involve much more than that implies. As Cohen (2013) observed in her study of job assembly, the boundaries around jobs enclosed much more than a set of tasks and a title:

They enclosed the people who performed and managed them, the competencies and experiences of those actors, technology, formal and informal rewards, locations in a status hierarchy, human resources policies, bureaucratic rules and regulations, as well as the various requirements that each of these elements produced (p. 459)

Indeed, jobs are critical links from micro to meso to macro. Jobs link individuals to organizations and organizations to occupations, legal structures, and other institutions (Cohen 2016). It is 
through jobs that all of these are instantiated in organizations. Occupations may span multiple organizations and jobs (Anteby, Chan \& DiBenigno, 2016) but this does not mean that occupations are somehow subsumed by occupations. It is through jobs that occupations have any presence in organizations. Not all jobs are part of occupations; however, jobs are part of all occupations. As such, jobs remain analytically distinct from occupations. They may be created and changed and destroyed independently of any occupational affiliations while at the same time are subjected to the same systemic and institutional pressures.

A core contribution of this volume is that many of the papers explore these intersections with jobs: how jobs are shaped by and shape organizations, occupations, and institutions. While we have developed rich traditions of researching individuals, organizational, occupational, legal, and institutional structures, jobs have been the subject of far less study and present an exciting opportunity for further scholarship, one that is taken up by many of the papers of this volume though in many different ways.

\section{THE PAPERS IN THIS VOLUME AS A FIRST STEP}

The papers in this edited volume represent a first step toward the multi-level, job-focused approach to the study of work that we envision. As a starting point on this agenda, we focus our attention in this volume on work within organizations - as opposed to independent contracting

and self-employment - because this has been and continues to be the dominant site of employment for most workers. Of course we recognize the ascendance of the "gig economy" and hope that future work will take on the challenge of examining these new jobs from a multilevel perspective.

We start with the assumption that organizations are the arena in which most individuals inhabit jobs. But we recognize that the ways in which the jobs are defined, the power and autonomy they engender, the opportunities that are afforded and the constraints that are imposed are continuously contested not only at the individual level, but also at a more aggregate and collective level.

Although we don't yet have clear answers, there are some broad themes and emergent perspectives on what shapes work evident in the papers in this volume. They are united in that they all somehow rely on the notion of a role or job - a bundle of tasks performed by an employee under an administrative job title (Cohen, 2013, p. 432) - as a focal analytic construct. Some papers consider the individual and organizational forces that shape the boundaries and content of jobs and more generally of work. Others consider how jobs and work shape organizational and societal outcomes. Still others consider the interplay between these levels.

We start with a set of papers that are explicit in considering jobs as fundamental building blocks of organizational and societal structures. The first paper reconceptualizes jobs by embracing this multi-level approach. In "Jobs as Gordian Knots: A New Perspective Linking Individuals, Tasks, Organizations and Institutions," Cohen argues that jobs must be considered as more than the disembodied and atomized units of tasks and titles held within organizational boundaries so often depicted. She reconceptualizes jobs as a series of ties that span levels to structures and 
individuals within the job and the organization and beyond the organization. These ties link jobs into an organizational job structure that cannot be understood merely as the sum of individual jobs. She proposes that these ties form a series of Gordian Knots that can explain patterns of inertia and change for jobs and organizations and that can usefully inform models of organizational mobility and inequality. She develops a program of research that would bring jobs more fully into the study of work and organizations.

In their paper "Idiosyncratic Jobs, Organizational Transformation and Career Mobility," Miner and Akinsanmi (2016) also question the dominant conceptualizations of jobs. Miner and Akinsanmi does this by reviewing the body of work on idiosyncratic jobs - jobs whose formal duties are based on an employee's interests and/or capabilities. The existence of such jobs draws into question the basic assumptions of the more mainstream job design research, in particular that the bundle of duties within a given job precedes the job incumbent - what she labels the vacancy assumption. In her review, she shows that these jobs have effects - sometimes positive that extend far beyond those for individual incumbents. Idiosyncratic jobs can lead to lasting change in organizational structures, learning, and altered mobility opportunities and career pathways within and across organizations. She proposes integrating research on idiosyncratic jobs with research on individual jobs -- job crafting, idiosyncratic deals, and negotiated joining and ecologies of jobs.

The final paper in this section, "The Ideology of Silence at the Harvard Business School: Structuring Faculty's Teaching Tasks for Moral Relativism," considers one effect of designing tasks that prevent others from being performed within a given job. Anteby (2016) analyzes the organizational artifact of the case teaching notes used by professors at the Harvard Business School to examine faculty members' and students' ability to uphold a shared moral stand in the classroom. The artifacts surrounding a job can be used to socialize incumbents on what tasks can or cannot be performed within that job. In this instance, the teaching tasks specified in the notes refrain from passing judgment on any students' moral viewpoints. Anteby (2016) shows how the silence of case teaching notes on any moral question that might arise in class discussions allows moral relativism to flourish among the future business leaders. In effect, through the structuring of faculty members' teaching tasks or this engineered silence, moral relativism prevails. This paper suggests that understanding the structuring of tasks into jobs can provide important insights into societal-level phenomenon.

The second set of papers in this volume examines the dynamics of professional and occupational boundaries. In "What Do Technicians Mean When They Talk About Professionalism? An Ethnography of Speaking," Barley, Bechky and Nelson (2016) uncover how technicians invocations of "profession" often aim to foster respect for their expertise by reinforcing horizontal boundaries in the division of labor. This is in contrast to conventional assumptions that professional talk aims more at mobility in the vertical division of labor. They draw on a novel set of coordinated ethnographies of technical occupations that undergird a comparative database on the social organization of technicians' work, highlighting the power of detailed explorations of what workers do. Such research allows us to probe and demystify assumptions and claims made by more macro research on organizations, occupations and professions, thus encouraging richer, multi-level understandings of structuration of work in and across organizations. 
Sandholtz and Burrows (2016), in their paper, "Compliance Police or Business Partner? Institutional Complexity and Occupational Tensions in Human Resource Management," use historical and ethnographic research to explore the problem of boundaries in human resource (HR) departments. They draw on the institutional logics perspective (Thornton et. al., 2012) to understand how the initial compliance focus of HR evolved into strategic HR. This shift subjected HR professionals to multiple competing demands associated with being a "business partner" to various other organizational departments and functions. Thus, the expansionist efforts of the HR profession to become more strategic has had unintended consequences associated with heteronomy, and this creates new problems and tensions for the jobs and work of HR staff. This paper highlights the utility of situating ethnographic understandings of work amidst broader institutional processes involving professional projects and other field-level dynamics.

The third set of papers examines constraints on the work done in organizations and the constraints coming from that work: What shapes work and what does work shape? In "Structure at Work: Organizational Forms and the Division of Labor in U.S. Wineries," Haveman, Swaminathan and Johnson (2016) look at how organizational identity, linked to the social codes of categories, shapes the structure of work in organizations. In the context of wineries, they show that the codes associated with wineries' generalist and specialist forms constrain the number of distinct jobs and functional areas delineated by job titles, as well as job idiosyncrasy. They highlight how such constraints are stronger when social codes are elaborated and widely agreed upon, but also contingent on the legitimacy and resources of organizations. This paper highlights the importance of broader institutional influences on job structures, but much more research is needed. It would be especially helpful to couple this kind of institutional analysis with more grounded, ethnographic understandings of the work being done across different categories of organization.

Kurkoski (2016) considers both the opportunity and constraint that arise from network position within a firm. In her paper, "It's Not You, It's Your Job: Network Evolution within Firms," she follows a set of similarly qualified new hires and demonstrates how their career and work experiences are strongly shaped by a seemingly random initial assignment. In doing so she highlights how jobs are embedded in social structure and that social structure is a hidden source of both opportunity and constraint that operates independent of individual skills or qualifications.

In "Help Me Do It On My Own: How Entrepreneurs Manage Autonomy and Constraint Within Incubator Organizations," Seidel, Packalen and O'Mahony (2016) explore how the work of entrepreneurs is enabled as well as constrained by their participation in incubators and accelerators. While we conventionally think of these entrepreneurial-generating institutions as mainly enablers for young entrepreneurs, the authors draw on field observation, interviews, and archival data to show how they also can foster conflict, dissonance, and a loss of autonomy. By foregrounding this conflict between corporate and entrepreneurial logics, this paper, echoing the Sandholtz and Burrow's (2016) paper, demonstrates the value of cross-level research that can uncover how managing the institutional complexity associated with competing logics is a pervasive phenomenon across all types of work. 
The fourth set of papers focus on how structures are perpetuated and changed and emphasize broader institutional and political forces that impact the nature of work. Alexander (2016), a legal scholar, illustrates how employers are able to structure work in order to avoid legal liability and compliance costs. Her broad paper (Legal Avoidance and the Restructuring of Work) draws upon a variety of studies and calls into question both the task and individual preference lenses on work. Alexander (2016) instead highlights strategic action on the part of employers interacting with a legal regime that has the potential to systematically disadvantage workers, particularly already vulnerable marginal and low-wage workers. Riordan and Osterman (2016) similarly emphasize firm strategic action, but focus on what has historically been the high-end of the labor market. In their paper, "Externalization of Work by Corporate Law Firms," they show how the "unbundling" of work within large corporate law firms negatively impacts the career prospects of law school graduates, amplifies stratification within the legal profession, generates firm heterogeneity with in the legal industry, and affects the organizational design of law firms. In their paper "Work as Commons: Internal Labor Markets, Blended Workforces, and Management," Camuffo and De Stefano (2016) make a plea to managers to take more responsibility for their organizational and job design choices and to recognize the societal impact of work policies and practices. Their paper forges a moral linkage between managerial decisions and social consequences.

The final paper in this section and in this volume examines the work of managers in moving and translating outside practices into internal organizational reality. In "From Adapting Practices to Inhabiting Ideas: How Managers Restructure Work Across Organizations," Huising (2016) draws on rich qualitative data from a study of managers involved in implementing Business Process Reorganization (BPR) to show how managers alter the practices associated with BPR as they implement this program within their organizations. While they remain strong believers in the program, overtime they increasingly inhabit the practices and alter the specific activities in accordance with organizational history and context. This paper goes beyond documenting variation across organizations in the practices associated with various programs to explain how they are inhabited within organizations.

As these brief summaries indicate, the volume includes conceptual as well as qualitative and quantitative empirical work. All of the chapters in some way attend to the details how work is executed on the "shop floor", but examine a range of employees across a variety of settings. The volume includes empirical studies both within and between organizations as well as within and between other key boundaries such as occupation, industry, geography and time. As a collection they offer examples of how we might pursue a multi-level understanding of the structure of work.

\section{CONClusion}

There is no shortage of calls to examine the interplay between organizations and work structure. These calls emanate from scholars with distinct disciplinary perspectives and methodologies (Barley \& Kunda, 2001; Baron, 1984; Baron \& Bielby, 1980; Baron \& Pfeffer, 1994; Beckman \& Burton, 2011; Kaghan \& Lounsbury, 2011; Lounsbury \& Kaghan, 2001). 
Those raising these calls provide many explanations for why there has not been more progress in this area of research: for instance, there is a theoretical vacuum around work; paradigm development related to work is weak; appropriately detailed data is not readily available; the collection of appropriate data is time intensive and difficult. All of these explanations are valid. We suggest that in addition there is another reason why more progress has not been made in this area: that there has not been a strong cohesive community of scholars to advance such an agenda. Scholars of work cross many disciplines, theoretical perspectives, methodologies, and geographies and this makes it difficult to gather critical mass and momentum in this area.

This volume presents new theoretical and empirical papers that examine aspects of the changing nature of jobs and work in organizations from multiple perspectives and multiple methodologies. The papers cover a variety of workers - technicians, professors, engineers, lawyers, managers, and HR professionals - different work settings including entrepreneurial incubators, wineries, high tech firms, large corporations, universities and hospitals. These papers have a common focus on taking structural and interactionist perspectives. They emphasize the extra-individual forces that influence how work is structured within organizations. They are united in emphasizing how jobs and tasks within organizations are shaped and constrained by external forces such as occupations, professions, legal regimes, institutional logics and competitive dynamics. We believe that they lay a foundation for renewed interest in and attention to the structure and structuring of work, and encourage more systematic scholarship in this direction.

\section{ACKNOWLEDGEMENTS}

This volume is the product of an interdisciplinary gathering of organizations scholars convened in the summer of 2013 with generous support of the Canadian Social Science and Humanities Research Council, the Organization and Management Theory Division of the Academy of Management. We gratefully acknowledge financial and in-kind support from our home institutions, Cornell University, McGill University, and the University of Alberta. We thank the authors of the volume papers, all of whom were invited as mentors or participants. We would also like to recognize the mentors who provided valuable feedback and commentary at the event and have been and continue to be valued colleagues and collaborators: Christine Beckman, Forrest Briscoe, Emilio Castilla, and Marc Ventresca. We especially want to thank both Steve Barley and Jim Baron who have been mentors and inspirations to all of us.

\section{REFERENCES}

Abbott, A. (1989). The new occupational structure: What are the questions? Work and Occupations, 16, 273-291.

Adler, P.S. (2003). Towards collaborative interdependence: A century of change in the organization of work. In B.E. Kaufman, R.A. Beaumont, \& R.B. Helfgott (Eds.), Industrial Relations to Human Resources and Beyond: The Evolving Process of Employee Relations Management (pp. 353-359). Armonk, NY: M.E. Sharp. 
Alexander, C. S. (2016). Legal avoidance and the restructuring of work. In L. E. Cohen, M.D. Burton and M. Lounsbury (Eds.), The structuring of work in organization (Vol. 47). Research in the Sociology of Organizations. Bingley, UK: Emerald Group Publishing Limited.

Anteby, M. (2016). The ideology of silence at the Harvard Business School: Structuring faculty's teaching tasks for moral relativism. In L. E. Cohen, M.D. Burton \& M. Lounsbury (Eds.), The structuring of work in organization. (Vol. 47). Research in the Sociology of Organizations. Bingley, UK: Emerald Group Publishing Limited.

Anteby, M., Chan, C. K., \& DiBenigno, J. (2016). Three lenses on occupations and professions in organizations: Becoming, doing, and relating. The Academy of Management Annals, 10(1), 183-244.

Autor, D. H. (2015). Why are there still so many jobs? The history and future of workplace automation. The Journal of Economic Perspectives, 29(3), 3-30.

Barley, S. R. (1996). Technicians in the workplace: Ethnographic evidence for bringing work into organizational studies. Administrative Science Quarterly, 41(3), 404-441.

Barley, S. R., Bechky, B., \& Nelson, B. (2016). What do technicians mean when they talk about professionalism? An ethnography of speaking. In L. E. Cohen, M. D. Burton \& M. Lounsbury (Eds.), The structuring of work in organization (Vol. 47). Research in the Sociology of Organizations. Bingley, UK: Emerald Group Publishing Limited.

Barley, S. R., \& Kunda G. (2001). Bringing work back in. Organization Science, 12(1), 76-95.

Barley, S. R., and Kunda G. (2004). Gurus, hired guns, and warm bodies: Itinerant experts in a knowledge economy. Princeton, NJ: Princeton University Press.

Baron, J. N. (1984). Organizational perspectives on stratification. Annual Review of Sociology, 10, 37-69.

Baron, J. N., \& Bielby W. T. (1980). Bringing the firms back in: Stratification, segmentation and the organization of work. American Sociological Review, 45, 737-765.

Baron, J. N., Dobbin, F. R., \& Jennings, P. D. (1986). War and peace: The evolution of modern personnel administration in U.S. industry. American Journal of Sociology, 92, 350-383.

Baron, J. N., Hannan, M. T., \& Burton, M. D. (1999). Building the iron cage: Determinants of managerial intensity in the early years of organizations, American Sociological Review, 64(4), 527-547.

Baron, J. N., Jennings, D., \& Dobbin, F. R. (1988). Mission control? The development of personnel systems in U.S. industry. American Sociological Review, 53, 497-514.

Baron, J. N., \& Pfeffer, J. (1994). The social psychology of organizations and inequality. Social Psychology Quarterly, 57(3), 190-209

Beckman, C., \& Burton, M. D. (2011) Bringing organizational demography back in: Time, change and structure in top management team research. In M. Carpenter (Ed.), The handbook of research on top management teams. New York, NY: Edward Elgar.

Briscoe, F. (2007). From iron cage to iron shield? How bureaucracy enables temporal flexibility for professional service workers. Organization Science, 18(2), 297-314.

Burton, M. D. (2001). The company they keep: Founders' models for organizing new firms. In C. B. Schoonhoven and E. Romanelli (Eds.), The entrepreneurship dynamic: Origins of entrepreneurship and the evolution of industries (pp. 13-39), Stanford, CA: Stanford University Press. 
Burton, M. D., \& Beckman, C. (2007). Leaving a legacy: Role imprints and successor turnover in young firms. American Sociological Review, 72, 239-266.

Burton, M. D., Sørensen, J. B., \& Beckman, C. M. (2002). Coming from good stock: Career histories and new venture formation. Research in the Sociology of Organizations, 19, 229262.

Camuffo, A. \& DeStefano, F. (2016). Work as commons: Internal labor markets, blended workforces and management. In L. E. Cohen, M. D. Burton, \& M. Lounsbury (Eds.), The structuring of work in Organizations (Vol. 47). Research in the Sociology of Organizations. Bingley, UK: Emerald Group Publishing Limited.

Chandler, A. D., Jr. (1990). Scale and scope: The dynamics of industrial capitalism. Cambridge, MA: Harvard University Press.

Cohen, L. E. (2013). Assembling jobs: A model of how tasks are bundled into and across jobs. Organization Science, 24, 432-454.

Cohen, L. E. (2016). Jobs as Gordian knots: A new perspective linking individuals, tasks, organizations and institutions. In L. E. Cohen, M. D. Burton, \& M. Lounsbury (Eds.), The structuring of work in organizations (Vol. 47). Research in the Sociology of Organizations. Bingley, UK: Emerald Group Publishing Limited.

Davis, G. F. (2009). Managed by the markets: How finance reshaped America. New York: Oxford University Press.

Davis, G. F. (2016). The vanishing American corporation: Navigating the hazards of the new economy. San Francisco, CA: Berrett-Koehler Publishers.

Dobbin, F., \& Sutton, J. (1998). The strength of a weak state: The rights revolution and the rise of human resources management divisions. American Journal of Sociology, 104(2), 441476.

Doeringer, P. B. \& Piore, M. J. (1971). Internal labor Markets and manpower analysis, Lexington, MA: Heath.

Edelman, L. B. (1992). Legal ambiguity and symbolic structures: Organizational mediation of civil rights law. American Journal of Sociology, 97, 1531-1576.

Ferguson, A. J., L. Cohen, L., Burton, M. D., \& Beckman, C. M. (forthcoming). Misfit and milestones: Structural elaboration and capability reinforcement in the evolution of entrepreneurial top management teams. Academy of Management Journal, August 2016, 59(3). Accessed online from July 20, 2015. doi: 10.5465/amj.2014.0526

Fligstein, N. (1990) The transformation of corporate control. Cambridge, MA: Harvard University Press.

Freeman, R., \& Medoff, J. (1984). What do unions do? New York, NY: Basic Books.

Freidson, E. (2001). Professionalism: The third logic. Chicago, IL: University of Chicago Press. Freidson, E. (Ed.). (1973). Professions and their prospects. Beverly Hills, CA: Sage.

Goh, J., Pfeffer, J., \& Zenios, S. (2015). Exposure to harmful workplace practices could account for inequality in life span across different demographic groups. Health Affairs 34(10), 1761-178.

Grant, A. M. \& Parker, S. K. (2009). Redesigning work design theories: The rise of relational and proactive perspectives. Academy of Management Annals, 3(1), 317-375.

Hackman, J. R., \& Oldham, G. R. (1980). Work redesign. Reading, MA: Addison-Wesley. 
Harris, S. D., \& Krueger, A. B. (2015). A proposal for modernizing labor laws for twenty-firstcentury work: The independent worker. Discussion Paper No. 2015-10. The Hamilton Project. Brookings Institution, Washington D.C.

Haveman, H. A., \& Cohen, L. E. (1994). The ecological dynamics of careers: The impact of organizational founding, dissolution and merger on job mobility. American Journal of Sociology, 100, 104-152.

Haveman, H. A., Swaminathan, A., \& Johnson, E. B. (2016). Structure at work: Organizational forms and the division of labor in U.S. wineries.

Hipple, S. F. (2010). Self-employment in the United States. Monthly Labor Review, September, 17-32.

Hout, M. (2015). A summary of what we know about social mobility. The Annals of the American Academy of Political and Social Science, 657, 27-36

Huising, R. (2016). From adapting practices to inhabiting ideas: How managers restructure work across organizations. In L. E. Cohen, M. D. Burton, \& M. Lounsbury (Eds.), The structuring of work in organizations (Vol. 47). Research in the Sociology of Organizations. Bingley, UK: Emerald Group Publishing Limited.

Kaghan, W., \& Lounsbury, M. (2011). Institutions and work. Journal of Management Inquiry 20(1), 73-81.

Klein, K. J., \& Koslowski, S. W. J. (Eds.). (2000). Multilevel theory, research, and methods in organizations: Foundations, extensions, and new directions. San Francisco, CA: JosseyBass

Kurkoski, J. (2016). It's not you it's your job: Network evolution within firms. In L.E. Cohen, M. D. Burton \& M. Lounsbury (Eds.), The structuring of work in organizations (Vol. 47). Research in the Sociology of Organizations. Bingley, UK: Emerald Group Publishing Limited.

Licht, W. (1991). Studying work: Personnel policies in Philadelphia firms, 1850-1950. In S. M. Jacob (Ed.). Masters to managers: historical and comparative perspectives on American employers (pp. 43-73). New York, NY: Columbia University Press.

Lounsbury, M. (2001). Institutional sources of practice variation: Staffing college and university recycling programs. Administrative Science Quarterly, 46, 29-56.

Lounsbury, M. (2007). A tale of two cities: Competing logics and practice Variation in the professionalizing of mutual funds. Academy of Management Journal, 50, 289-307.

Lounsbury, M., \& Kaghan, W. N. (2001). Organizations, occupations and the structuration of work. In S. P. Vallas (Ed.), Research in the Sociology of Work (Vol. 10, pp. 25-50). Oxford: JAI Press.

Miller, A. R., Treiman, D. J., Cain, P. S., \& Roos, P. A. (Eds.). (1980). Work, jobs, and occupations: A critical review of the dictionary of occupational titles. Final Report to the U.S. Department of Labor by the Committee on Occupational Classification and Analysis, National Research Council. National Academy Press, Washington, D.C.

Miner, A. S. (1990). Structural evolution through idiosyncratic jobs: The potential for unplanned learning. Organization Science, 1, 195-210.

Miner, A. S. (1991). Organizational evolution and the social ecology of jobs. American Sociological Review, 56, 772-785.

Miner, A. S., \& Akinsanmi, O. (2016). Idiosyncratic jobs, organizational transformation, and career mobility. In L. E. Cohen, M. D. Burton, \& M. Lounsbury (Eds.), The structuring of 
work in organizations (Vol. 47). Research in the Sociology of Organizations. Bingley, UK: Emerald Group Publishing Limited.

Oldham, G. R., \& Hackman, J. R. (2010). Not what it was and not what it will be: The future of job design research. Journal of Organizational Behavior, 31, 463-479.

Parker, S. K., \& Wall, T. D. (1998). Job and work design: Organizing work to promote well-being and effectiveness. Thousand Oaks, CA: Sage.

Pfeffer, J., \& Baron, J. N. (1988). Taking the workers back out: Recent trends in the structuring of employment. Research in Organizational Behavior, 10, 257-303.

Riordan, C., \& Osterman, P. (2016). Externalization of work by corporate law firms: Implications for careers and the profession. In L. E. Cohen, M. D. Burton \& M. Lounsbury (Eds.), The structuring of work in organizations (Vol. 47). Research in the Sociology of Organizations. Bingley, UK: Emerald Group Publishing Limited.

Sandholtz, K. W., \& Burrows, T. N. (2016). Compliance police or business partner? Institutional complexity and occupational tensions in human resource management. In L. E. Cohen, M. D. Burton \& M. Lounsbury (Eds.), The structuring of work in organizations (Vol. 47). Research in the Sociology of Organizations. Bingley, UK: Emerald Group Publishing Limited.

Schoonhoven, C. B., \& Dobbin, F. (2010). Stanford's organization theory renaissance, 19702000 (Vol. 28). Research in the Sociology of Organizations. Bingley, UK: Emerald Group Publishing Limited.

Scott, W. R. (2014). Institutions and organizations: Ideas, interests and identities (4 ${ }^{\text {th }}$ ed.). Los Angeles, CA: Sage.

Seidel, V. P., Packalen, K. A., \& O’Mahoney, S. (2016). Help me do it on my own: How entrepreneurs manage autonomy and constraint within incubator organizations. In L.E. Cohen, M. D. Burton, \& M. Lounsbury (Eds.), Work structure, and organizations (Vol. 47). Research in the Sociology of Organizations. Bingley, UK: Emerald Group Publishing Limited.

Smith, A. (1776) An inquiry into the nature and causes of the wealth of nations. London: W. Strahan and T. Cadell.

Strang, D., \& Baron, J. N. (1990). Categorical imperatives: The structure of job titles in California state agencies. American Sociological Review, 55, 479-95.

Taylor, F. W. (1911). The principles of scientific management. New York, NY: W.W. Norton.

Thompson, E. P. (1967). Time, work-discipline, and industrial capitalism. Past and Present 38, 56-97.

Thornton, P. H., Ocasio, W., \& Lounsbury, M. (2012). The institutional logics perspective: A new approach to culture, structure and process. Oxford: Oxford University Press.

Weil, D. (2014). The fissured workplace: Why work became so bad for so many and what can Be done to improve it. Cambridge, MA: Harvard University Press.

Williamson, O. E. (1985). The economic institutions of capitalism: Firms, markets, relational contracting. New York, NY: Free Press.

Wrzesniewski, A., \& Dutton, J. E. (2001). Crafting a job: Revisioning employees as active crafters of their work. Academy of Management Review, 26, 179-201. 